\title{
PENGARUH MODEL PEMBELAJARAN KOOPERATIF TIPE GROUP INVESTIGATION (GI) TERHADAP KEMAMPUAN PEMECAHAN MASALAH MATEMATIKA SISWA PADA MATERI PECAHAN KELAS VII
}

\author{
${ }^{1}$ Tasika br Tarigan, ${ }^{2}$ Irwan \\ ${ }^{1,2}$ Program Studi Pendidikan Matematika STKIP Budidaya Binjai, Indonesia \\ ${ }^{1)}$ E-mail :tasika091097@gmail.com \\ ${ }^{2)}$ E-mail :irwan_1009@yahoo.com
}

\begin{abstract}
ABSTRAK
Tujuan penelitian ini adalah untuk mengetahui pengaruh model pembelajaran kooperatif tipe group investigation (GI) terhadap kemampuan pemecahan masalah matematika siswa pada materi pecahan kelas VII SMP Swasta Setia Budi Binjai. Jenis penelitian ini merupakan penelitian quasi eksperiment (eksperimen semu) dengan desain penelitian pretest-posttest control group design. Populasi penelitian ini adalah siswa kelas VII SMP Swasta Setia Budi Binjai, dan pengambilan dengan teknik random sampling. Kelas yang dijadikan sampel adalah kelas VII-1 sebagai kelas eksperimen yang diberikan pembelajaran model group investigation (GI), dan kelas VII-2 sebagai kelas kontrol yang diberikan pembelajaran konvensional. Teknik analisis data dalam penelitian ini dengan menggunakan uji regresi sederhana. Berdasarkan hasil uji regresi diperoleh $F_{\text {hitung }} 1,49$ dan $F_{\text {tabel }} 2$ 2,79. Sehingga $F_{\text {hitung }}<F_{\text {tabel }}$ maka $\mathrm{H}_{0}$ diterima dan $\mathrm{H}_{a}$ ditolak. Berdasarkan uraian diatas dapat diambil kesimpulan bahwa terdapat pengaruh model pembelajaran Group Investigation (GI) terhadap kemampuan pemecahan masalah matematika siswa. Hal ini menunjukkan bahwa kemampuan pemecahan masalah matematika siswa pada kelas yang diberikan model pembelajaran GI lebih baik dibanding kelas yang diberikan pembelajaran konvensional. Kesimpulan hasil penelitian ini adalah bahwa pembelajaran matematika pada pokok bahasan pecahan dengan menggunakan model pembelajaran group investigation berpengaruh secara signifikan terhadap kemampuan pemecahan masalah matematika siswa dibandingkan yang menggunakan pembelajaran konvesional.
\end{abstract}

Kata kunci : Model Pembelajaran Kooperatif Tipe Group Investigation, Kemampuan Pemecahan Masalah Matematika Siswa.

\begin{abstract}
The purpose of this research was to knew the influence of Investigation Group (GI) learning type, of student problem solving skill about praction theory seventh grade student of private Setia Budi School Binjai. Type of the research was quasi eksperiment research (eksperimen semu) with pretest-posttest control group design research. The research population was the seventh grade student of private Setia Budi School Binjai, and the taking with random sampling technique. Student classroom used as a sample was seventh grade-one as experiment class that given group investigation (GI) learning type, and seventh grade-two as control class that given conventional learning type. Data analysis technique of the research used simple regression test. Based on the result of regression test was obtained $F_{\text {hitung }} 1,49$ and $F_{\text {tabel }} 2,79$. So that $F_{\text {hitung }}<F_{\text {tabel }}$ so $\mathrm{H}_{0}$ received, and $\mathrm{H}_{\mathrm{a}}$ rejected. Based on the description above can be concluded that, there was the influence of investigation group learning type to student mathematic problem solving skill. This showed that student mathematic problem solving skill of the classroom that was given investigation (GI) learning type better than the classroom that was given conventional learning type. The conclusion of this research was that mathematic learning of fractional subject by using investigation group (GI) learning type influenced significantly of student mathematic problem solving skill compared that used conventional learning type.
\end{abstract}

Keyword : Cooperative learning mode of investigation group type student mathematic problem solving skill. 


\section{PENDAHULUAN}

Matematika merupakan bidang studi yang dipelajari oleh semua siswa dari SD sampai Perguruan Tinggi. Ada banyak alasan tentang perlunya siswa belajar matematika. Menurut Cornelius (Abdurrahman: 2003) lima alasan perlunya belajar matematika karena matematika merupakan: (1)Sarana berpikir yang jelas dan logis, (2)Sarana untuk memecahkan masalah dalam kehidupan seharihari, (3)Sarana mengenal pola-pola hubungan dan generalisasi pengalaman, (4)Sarana untuk mengembangkan kreativitas, (5)Sarana untuk meningkatkan kesadaran terhadap perkembangan budaya.

Secara umum menurut Depdiknas tahun 2003 adapun tujuan mata pelajaran matematika untuk semua jenjang pendidikan dasar dan menengah agar siswa mampu: (1)Memahami konsep matematika, menjelaskan keterkaitan antarkonsep, dan mengaplikasikan konsep atau algoritma secara luwes, akurat, efisien, dan tepat dalam pemecahan masalah, (2)Menggunakan penalaran pada pola dan sifat, melakukan manipulasi matematika dalam membuat generalisasi, menyusun bukti, atau menjelaskan gagasan dan pernyataan matematika, (3)Memecahkan masalah yang meliputi kemampuan memahami masalah, (4)Mengkomunikasikan gagasan dengan simbol, tabel, diagram, atau media lain untuk memperjelas keadaan atau masalah, (5)Memiliki sikap menghargai kegunaan matematika dalam kehidupan, yaitu rasa ingin tahu, perhatian, dan minat dalam mempelajari matematika, serta sikap ulet dan percaya diridalam pemecahan masalah.

Berdasarkan tujuan mata pelajaran matematika salah satu yang terpenting adalah kemampuan pemecahan masalah, karena kemampuan pemecahan masalah merupakan tujuan umum pembelajaran matematika.
Pentingnya pemecahan masalah yang dikemukakan oleh Branca bahwa Kemampuan pemecahan masalah adalah jantungnya matematika. Hal ini sejalan dengan NCTM yang menyatakan bahwa pemecahan masalah merupakan bagian integral dalam pembelajaran matematika, sehingga hal tersebut tidak boleh dilepaskan dari pembelajaran matematika".

Kemampuan pemecahan masalah penting dimiliki oleh setiap siswa dengan beberapa alasan yaitu menjadikan siswa lebih kritis dan analitis dalam mengambil keputusan di dalam kehidupan. Selain itu, siswa yang memiliki kemampuan pemecahan masalah adalah siswa yang memiliki pemahaman yang baik tentang suatu masalah, mampu mengkomunikasikan ide-ide dengan baik, mampu mengambil keputusan, memiliki keterampilan tentang bagaimana mengumpulkan informasi yang relevan, menganalisis, dan menyadari betapa perlunya meneliti kembali hasil yang telah diperoleh.

Rendahnya kemampuan pemecahan masalah siswa juga dialami siswa SMP Swasta Setia Budi Binjai. Berdasarkan hasil tes siswa didapatkan bahwa siswa masih kesulitan dalam menentukkan informasi dan merencanakan langkah-langkah yang dibutuhkan untuk memecahkan masalah. Salah satu penyebab rendahnya kemampuan pemecahan masalah matematika siswa dikarenakan dalam proses pembelajaran dikelas siswa hanya menggunakan pembelajaran yang berpusat pada guru. Hal ini dikarenakan guru memulai pembelajarannya dengan membahas definisi, mengumumkan topik yang akan di bahas, dan mengerjakan soal-soal yang diberikan oleh guru. Sehingga dalam pembelajaran di kelas hanya terjadi interaksi satu arah dan hasil pembelajaran menjadi kurang optimal serta keaktifan siswa masih sangat kurang. Hal ini dapat dikatakan 
bahwa guru masih menggunakan pembelajaran konvensional.

Contoh masalah adalah sebagai berikut:

1. Mula-mula Martias membeli $8 \frac{3}{4} \mathrm{~kg}$ pupuk. Kemudian ia membeli lagi $4 \frac{3}{5} \mathrm{~kg}$. Dari pupuk yang dibeli itu, Martias hanya menggunakan sebanyak $7 \frac{3}{8} \mathrm{~kg}$. Berapa kilogram sisa pupuk yang belum digunakan?

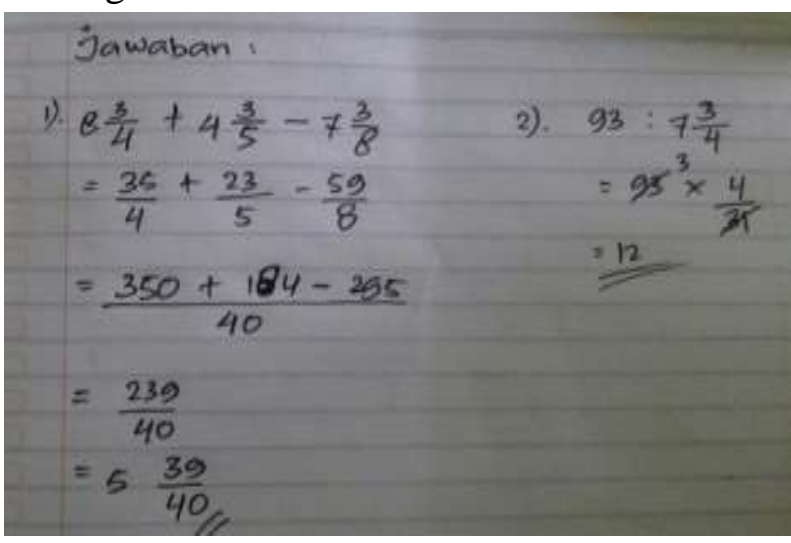

Gambar 1 Jawaban Siswa

Siswa tidak mampu memberikan penjelasan terhadap soal yang ada (menuliskan apa yang diketahui dan ditanya), siswa juga tidak mampu menuliskan perencanaan/ rumus yang akan digunakan dalam penyelesaian serta tidak melakukan pengecekan kembali. Seharusnya sesuai dengan langkah-langkah pemecahan masalah.

2. Sebuah drum berisi 93 liter minyak. Minyak itu dimasukkan ke dalam kalengkaleng kecil, yang masing-masing berisi $7 \frac{3}{4}$ liter. Berapa kaleng kecil yang diperlukan untuk diisi dengan seluruh minyak dari drum tersebut?

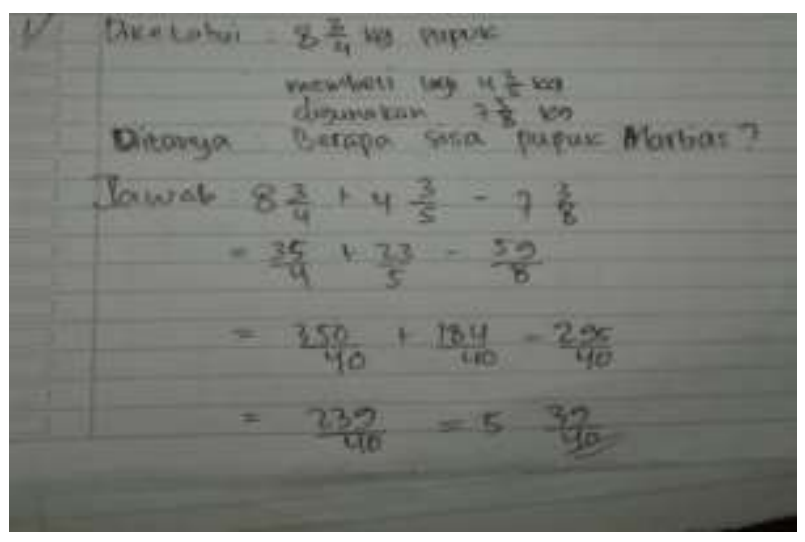

\section{Gambar 2 Jawaban Siswa}

Siswa tidak mampu menuliskan perencanaan/rumus yang digunakan dalam penyelesaian dan siswa tidak melakukan pengecekan kembali. Sehingga siswa tidak mampu melakukan langkah pemecahan masalah.

Kesulitan yang dialami siswa dalam memecahkan masalah matematika adalah kurangnya kebermaknaan materi yang diterima sehingga siswa sulit untuk membangun pengetahuan yang didapat. Menurut Hadi \& Radiyatul (2014) dan Nurianti, Halini, \& Ijudin (2015) bahwa siswa cenderung menghafal rumus tanpa memahami konsep dan mengerjakan masalah matematika dengan ceroboh. Siswa lebih senang menggunakan cara yang singkat tanpa memperhatikan proses penyelesaian dengan benar. Suasana pembelajaran juga mempengaruhi kemampuan pemecahan masalah siswa. Menurut pendapat Ulvah (2016) siswa yang terlibat aktif dalam proses pembelajaran memiliki kemampuan pemecahan masalah yang lebih baik daripada siswa yang tidak terlibat dalam pembelajaran. Melalui aktivitas pembelajaran yang baik, siswa tidak akan jenuh belajar sehingga kemapuan pemecahan masalah mereka dapat berkembang.

Menyikapi permasalahan yang timbul dalam pembelajaran matematika di sekolah SMP Swasta Setia Budi Binjai, perlu 
digunakan model pembelajaran yang mampu meningkatkan pemecahan masalah matematika siswa. Dalam hal ini harus dirancang kegiatan yang melibatkan siswa secara aktif dalam memaknai suatu materi pelajaran sehingga pembelajaran dapat dengan mudah diterima oleh siswa, maka untuk mengatasi permasalahan kemampuan pemecahan masalah di atas dibutuhkan suatu model pembelajaran yang mampu menciptakan suasana menyenangkan. Peneliti menerapkan model pembelajaran Group Investigation (GI) dimana model pembelajaran tersebutdapat meningkatkan keaktifan siswa dalam proses pembelajaran terlebih dalam kemampuan pemecahan masalah, serta interaktif dan mengarahkan siswa untuk lebih paham dalam langkah-langkah pemecahan soal matematika, terlebih untuk soal cerita.

\subsection{Model Pembelajaran Kooperatif Tipe Group Investigation (GI)}

\subsubsection{Model Pembelajarann Koopertaif}

Pembelajaran kooperatif atau cooperative learning berasal dari kata cooperative yang artinya mengerjakan sesuatu secara bersama-sama dengan saling membantu satu sama lainnya sebagai satu kelompok atau satu tim. Slavin mengemukakan, "in coperative learning method, students work together in four member teams to master material initially presented by the teacher". Sedangkan, Lie (2004:29) menyatakan strategi pembelajaran kooperatif adalah kegiatan belajar mengajar dalam kelompok-kelompok kecil, di mana peserta didik belajar dan bekerjasama untuk mendapatkan pengalaman belajar yang optimal, baik pengalaman individu maupun kelompok.

Sehingga model pembelajaran kooperatif adalah salah satu model pembelajaran yang dapat memberikan pengalaman belajar sendiri terhadap siswa dan membuat siswa memiliki sikap tanggung jawab dan mengembangkan sikap kreatif.

Arends menyatakan bahwa pelajaran yang menggunakan pembelajaran kooperatif memiliki ciri-ciri sebagai berikut: (1)Siswa bekerja dalam kelompok secara kooperatif untuk menuntaskan materi belajar, (2)Kelompok dibentuk dari siswa yang mempunyai kemampuan tinggi, sedang, dan rendah (heterogen), (3)Bila memungkinkan, anggota kelompok berasal dari ras, budaya, suku, jenis kelamin yang beragam, (4)Penghargaan lebih berorientasi kepada kelompok dari pada individu.

Tujuan pembelajaran kooperatif adalah siswa bekerja sama untuk belajar dan bertanggung jawab pada kemajuan belajar kelompoknya. Johnson \& Johnson (1994) menyatakan bahwa tujuan pokok belajar kooperatif adalah memaksimalkan belajar siswa untuk peningkatan prestasi akademik dan pemahaman baik secara individu maupun secara kelompok.

\subsubsection{Group Investigation (GI)}

Menurut Eggen \& Kauchak dalam Maimunah, mengemukakan Investigasi Kelompok (Group Investigation) adalah strategi belajar kooperatif yang menempatkan siswa ke dalam kelompok untuk melakukan investigasi terhadap suatu topik. Model pembelajaran group investigation (GI) diharapkan mampu menjadi solusi untuk meningkatkan kemampuan pemecahan masalah matematika siswa khususnya pada materi pecahan. Untuk itu peneliti tertarik mengadakan sebuahnpenelitian dibidang pendidikan matematika dengan judul "Pengaruh Model Pembelajaran Kooperatif Tipe Group Investigation (GI) Terhadap Kemampuan Pemecahan Masalah Matematika Siswa Kelas VII SMP Swasta Setia Budi Binjai Tahun Pelajaran 2019/2020”. Oleh karena itu tujuan dari penelitian ini adalah 
untuk mengetahui pengaruh model pembelajaraan kooperatif tipe group investigation (GI) terhadap kemampuan pemecahan masalah matematika siswa kelas VII SMP Swasta Setia Budi Binjai pada materi pecahan.

Dari uraian di atas maka dapat disimpulkan bahwa model group investigation adalah model pembelajaran secara kooperatif yang melibatkan siswa sejak awal sampai akhir proses pembelajaran (dari pemilihan materi sampai evaluasi). Model pembelajaran kooperatif tipe Group Investigation dianggap cocok untuk mengatasi permasalahan yang terjadi selama proses pembelajaran serta merubah motivasi serta minat siswa untuk lebih aktif dalam proses pembelajaran, dengan harapan melalui model tersebut keterampilan sosial siswa akan meningkat.

Sharan membagi langkah-langkah pelaksanaan model group investigation meliputi 6 (enam) fase yaitu:

1) Memilih Topik

Siswa bersama guru memilih dan menentukan subtopik dengan lingkup permasalahan yang umum. Siswa juga dikelompokkan menjadi beberapa kelompok kecil yang heterogen dengan anggota 2-6 anggota.

2) Perencanaan Kooperatif

Siswa dan guru merencanakan prosedur pembelajaran, tugas dan tujuan khusus yang konsisten dengan subtopik dari permasalahan yang telah dipilih pada tahap pertama.

3) Implementasi

Siswa menerapkan rencana yang telah mereka kembangkan di dalam tahap kedua. Kegiatan pembelajaran hendaknya melibatkan ragam aktivitas dan keterampilan yang luas. Guru secara ketat mengikuti kemajuan tiap kelompok dan menawarkan bantuan bila diperlukan.
4) Analisis dan Sintesis

Siswa menganalisis dan menyintesis informasi yang diperoleh pada tahap ketiga dan merencanakan bagaimana informasi tersebut diringkas dan disajikan dengan cara yang menarik sebagai bahan untuk dipresentasikan kepada seluruh kelas.

5) Presentasi Hasil Final

Beberapa atau semua kelompok dipersilahkan untuk mempresentasikan hasil diskusi kelompok mereka, sedangkan kelompok yang lain saling terlibat satu sama lain. Dalam tahap ini, guru mengkoordinir kelompok yang akan mempresentasikan hasil diskusinya.

6) Evaluasi

Dalam tahap evaluasi ini, guru bersama siswa mengevaluasi hasil diskusi siswa tentang subtopik yang telah mereka tentukan bersama. Evaluasi yang dilakukan dapat berupa penilaian individual atau kelompok.

\subsection{Kemampuan Pemecahan Masalah}

Pemecahan masalah adalah proses dinamis di mana siswa mencoba untuk memahami situasi, membuat rencana untuk solusi, pilih atau mengembangkan metode dan strategi, menerapkan semua heuristik ini untuk mendapatkan solusi dan akhirnya mereka memeriksa jawaban yang diperoleh.Ruseffendi (2006) juga mengemukakan bahwa kemampuan pemecahan masalah amat penting dalam matematika, bukan saja bagi mereka yang dikemudian hari akan mendalami atau mempelajari matematika, melainkan juga bagi mereka yang akan menerapkannya dalam bidang studi lain dan dalam kehidupan seharihari.

Berdasarkan uraian di atas maka dapat disimpulkan bahwa dalam pemecahan masalah siswa didorong dan diberi kesempatan seluasluasnya untuk berinisiatif dan berfikir sistematis dalam menghadapi suatu masalah 
dengan menerapkan pengetahuan yang didapat sebelumnya. Sedangkan kemampuan pemecahan masalah matematika merupakan kemampuan siswa untuk menyelesaikan atau menemukan jawaban dari suatu pertanyaan yang terdapat didalam suatu cerita, teks, dan tugas-tugas dalam pelajaran matematika.

$$
\text { Adapun indikator kemampuan }
$$
pemecahan masalah menurut Polya yaitu: (1)Memahami masalah, (2)Menyusun rencana penyelesaian, (3)Melaksanakan rencana penyelesaian masalah, (4)Melakukan pengecekan kembali,

Polya menyebutkan bahwa ada beberapa langkah pemecahan masalah yaitu:

1) Memahami masalah

Tahap memahami masalah pada penelitian ini tahap dimana individu mampu memahami apa yang dimaksud dari soal atau masalah yang diberikan. Pada tahap memahami masalah ada beberapa indikator yang bisa dilihat antara lain yaitu mampu menentukan apa yang diketahui dan ditanyakan dari masalah tersebut, mampu menentukan kecukupan informasi dari masalah, dan menentukan syarat-syarat dalam menyelesaikan masalah yang harus dipenuhi.

2) Menyusun rencana penyelesaian

Pada tahap ini pemahaman konsep materi yang kuat sangat mempengaruhi keputusan penentuan rencana penyelesaian, jika pemahaman konsep seseorang baik maka akan mampu menghubungkan data dan tujuan yang akan dicapai, dengan begitu akan mudah menentukan alternatif atau dugaan penyelesaian dari masalah matematika tersebut.

3) Melaksanakan rencana penyelesaian masalah

Tahap ketiga adalah tahap melaksanakan rencana penyelesaian. Pada tahap ini rencana yang telah disusun akan dilanjutkan sesuai dengan cara-cara penyelesaian masalah yang diberikan. Pengalaman pemecahan masalah sangat berperan besar pada tahap ini.

4) Pengecekan kembali

Tahap terakhir adalah tahap memeriksa kembali, pada tahap ini indikasi tercapainya tahap memeriksa kembali adalah peserta didik memeriksa jawaban yang telah diberikan, jika memungkinkan dilakukan metode penghitungan kembali.

\section{METODOLOGI PENELITIAN}

Pendekatan penelitian ini adalah kuantitatif yang menggambarkan pengaruh model Group Investigation terhadap kemampuan pemecahan masalah matematika siswa. Penelitian ini merupakan penelitian dengan jenis penelitiannya adalah quasi eksperiment (eksperimen semu). Sebab kelas yang digunakan telah terbentuk sebelumnya.

Adapun desain pelaksanaan penelitian yang digunakan adalah pretest-posttest control group design.

\section{Tabel 1}

Desain Penelitian

\begin{tabular}{cccc}
\hline Kelas & $\begin{array}{c}\text { Pre- } \\
\text { test }\end{array}$ & Pembelajaran & $\begin{array}{c}\text { Post- } \\
\text { test }\end{array}$ \\
Eksperimen & $\mathrm{O}_{1}$ & $\mathrm{X}$ & $\mathrm{O}_{2}$ \\
Kontrol & $\mathrm{O}_{1}$ & - & $\mathrm{O}_{2}$ \\
\hline
\end{tabular}

Keterangan:

$\mathrm{O}_{1}:$ Pre-test yang diberikan sebelum Perlakuan

$\mathrm{O}_{2}$ : Post-test yang diberikan setelah diberi perlakuan

$\mathrm{X}$ : Perlakuan pada kelas eksperimen dengan menggunakan model pembelajaran Group Investigation. 
Populasi dalam penelitian ini adalah seluruh siswa kelas VII SMP Swasta Setia Budi Binjai yang terbagi menjadi 2 kelas yaitu kelas VII-1 dan VII-2 dengan jumlah siswa 60 siswa. Teknik sampling dalam penelitian ini menggunakan random sampling yaitu teknik pengambilan sampel secara acak. Sampel yang diambil dalam penelitian ini terdiri dari 2 kelas, satu kelas sebagai kelas eksperimen yaitu kelas VII-1 yang berjumlah 30 siswa dan satu kelas sebagai kelas kontrol yaitu kelas VII-2 yang berjumlah 30 siswa.

Dalam pelaksanaan penelitian ini ada dua variabel yang diukur yaitu variabel $X_{1}$ dan $X_{2}$. Variabel $X_{1}$ pada penelitian ini adalah tes kemampuan pemecahan masalah matematika siswa mengggunakan model pembelajaran group investigation (GI) pada kelas eksperimen, sedangakan variabel $X_{2}$ pada penelitian ini adalah tes kemampuan pemecahan masalah matematika siswa menggunakan pembelajaran konvensional pada kelas kontrol.

Teknik pengumpulan data yang digunakan dalam penelitian ini adalah teknik tes. Adapun instrumen penelitian yang akan digunakan dalam penelitian ini adalah tes kemampuan pemecahan masalah matematika siswa.

\section{HASIL DAN PEMBAHASAN}

Untuk memperoleh soal tes yang baik maka soal tes tersebut harus dinilai validitas, reliabilitas, tingkat kesukaran dan daya pembeda. Berdasarkan hasil uji coba soal hasil pengukuran validitas, reliabilitas, tingkat kesukaran dan daya pembeda tersebut diuraikan sebagai berikut.
Tabel 2

Rekapitulasi Validitas, Tingkat Kesukaran, Daya Pembeda, dan Reliabilitas Soal Pretest

\begin{tabular}{|c|c|c|c|c|c|}
\hline No & $\begin{array}{c}\text { Interpretasi } \\
\text { Validitas }\end{array}$ & $\begin{array}{c}\text { Interpretasi } \\
\text { Tingkat } \\
\text { Kesukaran }\end{array}$ & $\begin{array}{c}\text { Interpretasi } \\
\text { Daya } \\
\text { Pembeda }\end{array}$ & $\begin{array}{c}\text { Relia } \\
\text { bilitas }\end{array}$ & $\begin{array}{l}\text { Kesim } \\
\text { pulan }\end{array}$ \\
\hline 1 & 0,802 & 0,87 & 1,667 & & dipakai \\
\hline 2 & 0,744 & 0,723 & 1,8 & & dipakai \\
\hline 3 & 0,478 & 0,51 & 0,2 & 0,437 & dipakai \\
\hline 4 & 0,444 & 0,523 & 1 & & dipakai \\
\hline 5 & 0,629 & 0,47 & 1,53 & & dipakai \\
\hline
\end{tabular}

Tabel 3

Rekapitulasi Validitas, Tingkat Kesukaran, Daya Pembeda, dan Reliabilitas Soal Posttest

\begin{tabular}{cccccc}
\hline No Interpretasi & $\begin{array}{c}\text { Interpretasi } \\
\text { Validitas } \\
\text { Tingkat } \\
\text { Kesukaran }\end{array}$ & $\begin{array}{c}\text { Interpretasi } \\
\text { Daya } \\
\text { Pembeda }\end{array}$ & $\begin{array}{c}\text { Relia } \\
\text { bilitas }\end{array}$ & $\begin{array}{c}\text { Kesim } \\
\text { pulan }\end{array}$ \\
\hline 1 & 0,605 & 0,793 & 1,067 & & dipakai \\
2 & 0,737 & 0,757 & 1,4 & dipakai \\
3 & 0,793 & 0,797 & 1,667 & 0,395 & dipakai \\
4 & 0,786 & 0,763 & 1,667 & & dipakai \\
$\mathbf{5}$ & 0,819 & 0,753 & 2 & dipakai \\
\hline
\end{tabular}

Berdasarkan hasil analisis keseluruhan pada Tabel 2 dan Tabel 3 terhadap hasil coba tes kemampuan pemecahan masalah matematika siswa yang dilaksanakan di SMP Swasta Setia Budi Binjai maka dapat disimpulkan bahwa soal tersebut layak dipakai sebagai acuan untuk mengukur kemampuan pemecahan masalah matematika siswa.

Berdasarkan penelitian yang telah dilakukan, diperoleh data kemampuan pemecahan masalah matematika siswa dari hasil pretest dan posttest. Kemudian dilakukan uji normalitas dan uji homogenitas data pretest dan posttest pada kelas eksperimen dan kelas kontrol.

Pengujian normalitas data dilakukan dengan uji lilliefors. Uji liliefors digunakan untuk mengetahui apakah data berasal dari populasi yang berdistribusi normalatau tidak. dengan ketentuan bahwa data berasal dari populasi yang berdistribusi normal jika memenuhi kriteria $L_{o}<L_{\text {tabel }}$ dan demikian sebaliknya. Hasil uji normalitas data pretest disajikan dalam tabel berikut: 
Tabel 4

Uji Normalitas Data Pretest

\begin{tabular}{lll}
\hline \multicolumn{1}{c}{ Kelompok } & $\boldsymbol{L}_{\boldsymbol{o}}$ & $\boldsymbol{L}_{\text {tabel }}$ \\
\hline Eksperimen & $-0,0106$ & 0,161 \\
Kontrol & $-0,0156$ & 0,161 \\
\hline
\end{tabular}

Tabel 5

Uji Normalitas Data Posttest

\begin{tabular}{|c|c|c|}
\hline Kelompok & $L_{o}$ & $L_{\text {tabel }}$ \\
\hline Eksperimen & $-0,0220$ & 0,161 \\
\hline Kontrol & $-0,0268$ & 0,161 \\
\hline
\end{tabular}

Pengujian dilakukan pada taraf signifikan 0,05. Dari tabel 4 dan tabel 5 diperoleh $L_{o}<L_{\text {tabel }}$ sehingga dapat disimpulkan bahwa data pretest dan posttest berdistribusi normal.

Untuk menguji homogenitas dari data yang diperoleh selama penelitian, digunakan uji Fisher. Untuk kriteria pengujian data sampel adalah homogen jika $F_{\text {hitung }}<$ $F_{\text {tabel }}$ pada taraf nyata $\alpha=0,05 . \quad \mathrm{Uji}$ homogenitas pretest pada kemampuan pemecahan masalah kelas eksperimen dan kontrol diperoleh $\quad F_{\text {hitung }}(1,37)<$ $F_{\text {tabel }}(1,85)$ dan data posttest kemampuan pemecahan masalah kelas eksperimen dan kontrol diperoleh $\quad F_{\text {hitung }}(1,29)<$ $F_{\text {tabel }}(1,85)$.

Pengujian hipotesis ini diujikan dengan menggunakan Uji Regresi Sederhana dengan kriteria $F_{\text {hitung }}=1,49$ dan $F_{\text {tabel }}=2,79$. Sehingga $F_{\text {hitung }}<F_{\text {tabel }}$ maka $\mathrm{H}_{0}$ diterima dan $\mathrm{H}_{a}$ ditolak. Berdasarkan uraian diatas dapat diambil kesimpulan bahwa terdapat pengaruh model pembelajaran Group Investigation (GI) terhadap kemampuan pemecahan masalah matematika siswa.

\section{KESIMPULAN}

Berdasarkan penelitian yang telah dilakukan, maka dapat disimpulkan bahwa penggunaan model pembelajaran Group Investigation berpengaruh terhadap kemampuan pemecahan masalah matematika siswa kelas VII pada materi pecahan di SMP Swasta Setia Budi Binjai tahun pelajaran 2019/2020.

Berdasarkan hasil uji regresi diperoleh $F_{\text {hitung }} 1,49$ dan $F_{\text {tabel }}=2,79$. Sehingga $F_{\text {hitung }}<$ $F_{\text {tabel }}$ maka $\mathrm{H}_{0}$ diterima dan $\mathrm{H}_{a}$ ditolak. Berdasarkan uraian diatas dapat diambil kesimpulan bahwa terdapat pengaruh model pembelajaran Group Investigation (GI) terhadap kemampuan pemecahan masalah matematika siswa.

\section{DAFTAR PUSTAKA}

Argarini,Dian Fitri.2018. Analisis Pemecahan Masalah Berbasis Polya Pada Materi Perkalian Vektor Ditinjau Dari Gaya Belajar.Jurnal Matematika dan Pembelajaran. 6(1): 92.

Dwi,Putra,Harry dkk.2018. Kemampuan Pemecahan Masalah Matematis Siswa SMP pada Materi Bangun Ruang. Jurnal Ilmiah Pendidikan Matematika. 6(2): 83.

Effendi,LAdhar.2012.Pembelajaran Matematika Dengan Metode Penemuan Terbimbing Untuk Meningkatkan Kemampuan Representasi Dan Pemecahan Masalah Matematis Siswa SMP. Jurnal Penelitian Pendidikan. $13(32): 2$.

Fahradina,Nova,dkk. 2014.Peningkatan Kemampuan Komunikasi Matematis dan Kemandirian Belajar Siswa SMP Dengan 
Menggunakan Model Investigasi Kelompok. Jurnal Didaktit Matematika. 1(1): 54.

Hamdani,Dedy.2010. Penerapan Model Pembelajaran Kooperatif Tipe Investigasi Kelompok Dengan Media Software Microsoft Power Point Untuk Meningkatkan Hasil Belajar Siswa Di Kelas XI IPA 1 MAN Model Kota Bengkulu. Jurnal Exacta. 8(2): 57.

Handayani,D.2017. Pengaruh Model Problem Based Learning Terhadap Kemampuan Pemecahan Masalah Matematis Siswa Di Kelas VIII MTs.Al-Washliyah Tahun Ajaran 2016/2017 [Skripsi]. Sumatera Utara (ID): UIN.

Hijab, Alvia, dkk. 2016. Pengaruh Model Pembelajaran Group Investigation (GI) Terhadap Kemampuan Pemecahan Masalah Matematis Siswa Pada Materi Peluang Kelas X MIPA. Jurnal Pendidikan Matematika Indonesia. 1(1): 28.

Ibrahim Bayazit. An Investigation of Problem Solving Approaches, Strategies, and Models Used by the 7th and 8th Grade Students when Solving Real-World Problems.Erciyes University, 2013, hlm.1922.

Masniari. Pengaruh Pendekatan Konstektual Terhadap Kemampuan Pemecahan Masalah Matematika Siswa. Universitas Lampung. Jurnal Pendidikan Matematika, Vol.2, No.7, Oktober 2014, hlm.2.

Rasiman.Leveling Of Students' Critical Ability In Solving Mathematics Problem Based On Gender Differences. University of PGRI,Indonesia.International Journal of Education and Research, Vol.3, No.4, April 2015, hlm.308.
Suharsimi Arikunto. Prosedur Penelitian Suatu Pendekatan Praktek. (Jakarta: Rineka Cipta, 2010), hlm.174.

Trianto. 2009. Mendesain Model Pembelajaran Inovatif-Progresif. Jakarta: Kencana.

Trianto. 2007. Model-Model Pembelajaran Inovatif Berorientasi Konstruktivistik. Jakarta: Kencana.

Wahyuni, Rahmi. 2006. Pembelajaranan Kooperatif Bukan Pembelajaran Kelompok Konvensional. Jurnal Pembelajaran Kooperatif. 3(1):38. 